\title{
Environmental Burden Optimization in Distribution Pathways for Fruit Juice Product of Small Medium Enterprises Industry
}

\author{
Hermawan, Zulfa Fitri Ikatrinasari, Sawarni Hasibuan, Adriana Sari Aryani
}

\begin{abstract}
Fruit Juice products from Small Medium Enterprises (SMEs) Industry should be distributed immediately due to the life time the product less than 30 days. The purposes of this research in to minimize environmental burden during delivery of fruit juice product produced by SMEs to their customer. The customers of SMEs Fruit Juice Industry mainly are Hotel, Restaurant, and customer pack. One of Fruit Juice SMEs Industry located in Jabotabek area, provide service for at least 143 Hotel with 25671 rooms, distributed in 9 Zone in Jakarta, Banten and West Java. Total demand of fresh fruit juice of Hotels for all zones is 43,250 kg weekly. Optimization of fruit juice products distribution calculated by using truck with 1.5 ton capacity. Numbers of truck that recommend operating are 32 units with total route distance ideally only 3,112.20 Km/week. But normally in consideration to heavy traffics, the route distance are $4,081.45 \mathrm{Km} / w e e k$. The optimal diesel fuels consumption ideally are 414,96 liter/week and normally including traffic jam will consume diesel fuels are 544,19 liter/week. The Environmental Burden of fruit juice distribution process, represent by $\mathrm{CO}_{2}$ emission from fuels combustion ideally are 1.22-1.32 Ton/week. However, the normally condition with consideration to traffic jam, $\mathrm{CO}_{2}$ emission from fuels combustion are 1.60-1.73 Ton/week.
\end{abstract}

Index Terms: Product Distribution Pathway, Environmental Burden, Fruit Juice SMEs Industry.

\section{INTRODUCTION}

Indonesia is a country that produces various types of fruit and potential to be developed into processed fruit products such as fruits in cans, fruit juices, candies, jams and other processed fruit products. Indonesian fruit exports to the world market according to FAO data in 2009 rose by $11 \%$ [6]. Meanwhile, the Central Bureau of Statistics recorded an increase in export of processed fruit products $135.63 \%$ in the Year 2017 compared to the year 2013. Fruit juice production also increased export value in 2017 by $134.68 \%$ compared to the year 2013 [1].

In the fruit processing industry roadmap compiled by the Ministry of Industry in 2009, the fruit processing industry cluster was developed in West Java, East Java, South Sulawesi and North Sumatra. The long-term strategy of 2015-2025 from the Ministry of Industry is the development of fruit industry which is integrated with raw materials. From

Revised Manuscript Received on April 25, 2019.

Hermawan, Department of Computer Science, UniversitasPakuan Bogor, Indonesia.

ZulfaFitriIkatrinasari, Department of Industrial Engineering, UniversitasMercubuana, Jakarta, Indonesia.

SawarniHasibuan, Magister Program of Industrial Engineering, UniversitasMercubuana, Jakarta, Indonesia.

Adriana Sari Aryani, Department of Computer Science, UniversitasPakuan Bogor, Indonesia. the number of productive trees of the period 2012-2016, most are pineapple, orange, banana and mango.

The Ministry of Industry of the Republic of Indonesia (2009) identified several problems in the fruit processing industry are : a) raw materials (supply sustainability, post harvest technology, and quality consistency); b) production (low innovation, sanitation and food security, research and development, and industrial environmental management); c) marketing; and d) infrastructure security, research and development, and industrial environmental management.

The marketing issues in industry 4.0 today are no longer relevant to channels or transporters as business models have evolved more efficiently. Environmental issues are now being considered in transportation systems, especially transportation of beverage products. The problem of transportation of product delivery and collection of packaging that is returned to the factory becomes unity with environmental aspect for the product itself. In addition to improvements to the means of transport for the refinement of fuel combustion, the use of fuel is more environmentally friendly, and then the study of system optimization can be a separate study. The optimization of transportation routes to obtain the shortest travel time in the circulation of products, assessed as one effort to reduce the burden of the environment.

The environmental burden optimization study of the distribution line of small and medium-sized fruit juice products is done in an effort to provide the most recommended alternative to reduce environmental load when product distribution is done. In this case, the transport of the product is carried out in a very limited area adapted to the durability of the product. So that the mode of transportation that is used is a four-wheeled vehicle transport air cooled. The most dominant environmental indicator considered is $\mathrm{CO}_{2}$ emissions from transport.

\section{FRUITS PROCESSING INDUSTRY}

Puree products are produced directly from fresh fruit and are primarily processed fruit products which are widely traded among countries into raw materials for syrup production and fruit juice drinks.

Indonesia is a large importer of fruit puree since the domestic production is decrease [6]. Satuhu (2004) explains that international trade distinguishes fruit juice products based on the total content of dissolved solids and the content 


\section{Environmental Burden Optimization in Distribution Pathways for Fruit Juice Product of Small Medium Enterprises Industry}

of the pure juice [14]. This classification is known as fruit syrup, crush, cordial, unsweetened juice, ready served fruit beverage, nectar, squash and fruit juice concentrate.

The fruit juice industry in Indonesia is generally concentrated in big cities with limited marketing reach. Fruit juice drinks are circulated widely to the inter-island is only large industrial products that have been using aseptic packaging, either in the box (tetra pack) or aseptic bottles. SMEs industries generally still only rely on pasteurization so that the durability of the product is less than 30 days.

The SMEs fruit juice industries have a variety of market segments in limited geographical locations for consumption in the not-too-distant future. In large cities in the Greater Jakarta area or "Jabotabek" (Jakarta, Bogor, Tangerang and Bekasi), a number of hotels and restaurants are important markets for the SMEs fruit juice industry. The hotel as the juice industry market is divided into several zones as Fig. 1. Sales of fruit juices to hotels and restaurants are packed in bulk systems using jerry cans so it is generally reused with refill system. Direct sales are causing various transportation problems.

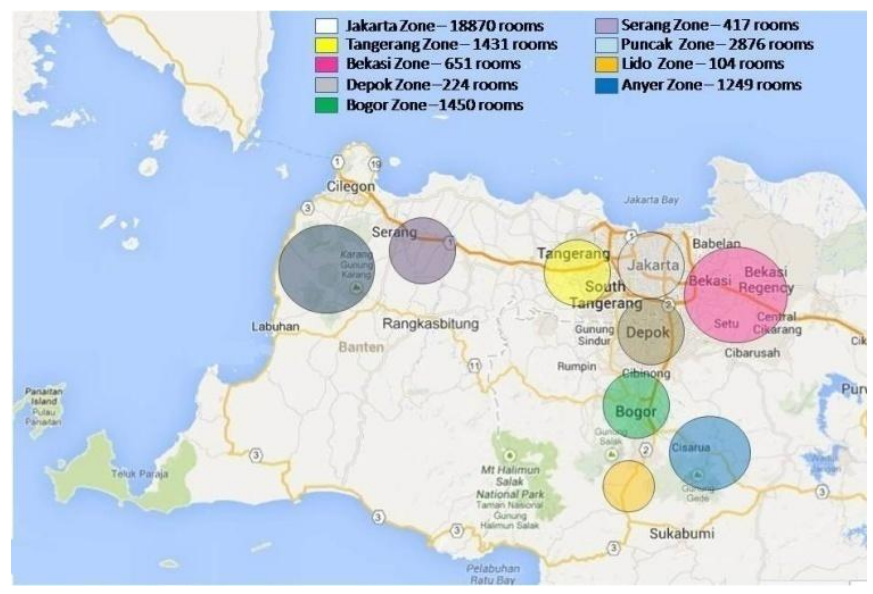

Fig. 1. Zoning and number of hotel rooms that are customers of fruit juice industry in West Java-Jakarta-Banten region

Determination of the route to be taken should correspond to the best distance between one hotel with another hotel. In addition to the route, the capacity of the vehicle to the weight of goods to be carried should also be considered. Two things become very important, because it can affect the quality of the process of distributing goods. The better the quality of the goods distribution process, the greater the benefits to be gained. On the contrary, the poor quality of goods distribution process will reduce the profitability of product sales [2].

In the area of supply chain management, several issues have been addressed under the terms 'green supply chain', 'supply chain sustainability' [10], and integrated chain management [15]. Environmental aspects refer to examples of $\mathrm{CO}_{2}$ emissions reductions, eco friendly product development, and reduced packaging [17].

Environmentally friendly supply chain management according to Hermawan (2007) is a supply-supply process supply from several parties involved in the circulation and utilization of a product. The principle of environmentally friendly supply chain are: 1) receiving "green" products, ie products produced with environmentally friendly rules; 2) ensuring supply lines that have the least environmental impacts; 3) assessment of suppliers' subcontractors; and 4) the supplier sub-contracting Program.

Transportation is an activity of moving goods from one place to another. Transportation is also one of the most important factors in the movement of supply chain, where the activities of transportation can have an impact in creating the timeliness and cost. Transportation is the movement of a product from one location to another that represents the beginning of a supply chain. [2].

\section{METHODS}

Research on SMEs fruit juice industry in Jabotabek area, has a widespread market consisting of Hotel, Restaurant, and Consumer Pack. In this case the research is focused only on Hotel consumers. Stages and methods of research conducted are presented in Fig. 2.

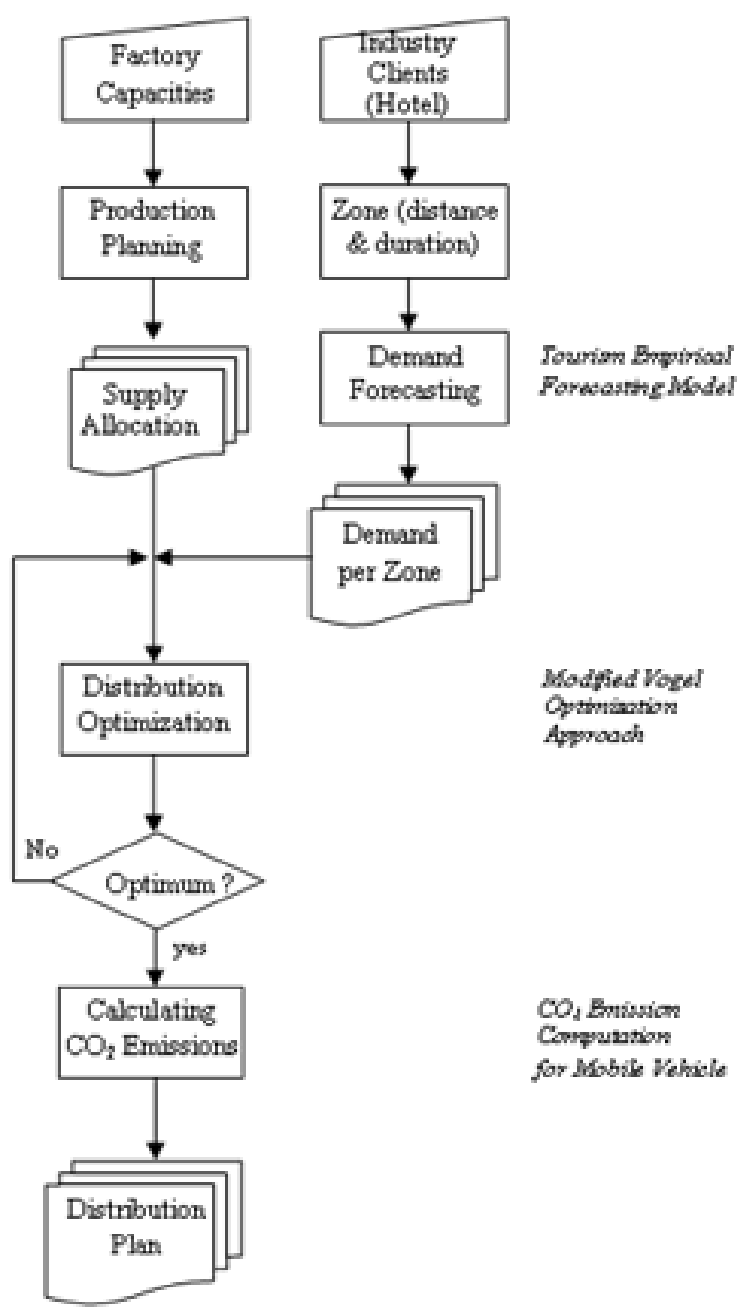

Fig. 2. Method \& Steps of Research

The estimation of the Hotel demand is calculated using the forecast of occupancy rate $(\mathrm{Oc})$ and length of stay $(\mathrm{St})$ of each region, using the Tourism Office data of each region that has been zoned. The formula is: 
$T E F M=2\left(\sum_{j=1}^{n} O c_{i} R_{i} S t_{i}\right)$

Guest $=2\left(\sum_{j=1}^{n} O c_{i} R_{i}\right)+T E F M$

Where is TEFM (Tourism Empirical ForecastingModel), Oc (Occupation rates in percentage), $R$ (Number of available rooms), St (length of stay per week), and $i$ is $i$-hotel. Juice consumption is calculated $200 \mathrm{ml}$ per guest with a tolerance of $10 \%$.

Distribution of juice products from factories completed by transportation method with formulation:

$a_{i}=$ the number of stuffing sources, where $i=2$ from the direct factory and the transit warehouse of Jakarta

$b_{j}=$ number of zoning stuffing, where $j=9$

$d_{i j}=$ is the distance between the source to the distribution zone.

Thenminimized:

$Z=\sum_{j=1}^{9} \sum_{i=1}^{2} x_{i j} d_{i j}$

Under the condition

$\sum_{j=1}^{9} x_{i j} \leq a_{i}$ and $\sum_{j=1}^{2} x_{i j} \geq b_{i}, x_{i j} \geq 0$

The simply ooptimizationsare solved with the Vogel algorithm.

The calculation of the environmental burden index from the transport of fruit juice delivery through the consumption of diesel fuel and exhaust gas emissions. Calculation of emissions with Direct Calculation based on fuel consumption. Calculation using the following equation (IPCC, 2006) [7]

Emission $=\left[\begin{array}{lll}\text { Fuel }_{\mathrm{a}} & \times \mathrm{EF}_{\mathrm{a}}\end{array}\right]$

Where, Emission = Specific pollutant emission load $(\mathrm{kg})$; Fuel $_{\mathrm{a}}=$ fuel consumption of type a (TJ); $\mathrm{FE}_{\mathrm{a}}=$ emission factor $(\mathrm{kg} / \mathrm{TJ}) \mathrm{a}=$ type of fuel (such as premium, diesel). The calculation of exhaust emissions of combustion is also conducted using emission factor based on national emission factor (Minister of Environment Regulation No. 12/2010 on Air Pollution Control in the Region), presented in Table 1.

Table 1. Vehicle Emission Factors (KLH, 2013)

\begin{tabular}{|c|c|c|c|}
\hline Emission & Gasoline car & Diesel car & Truck \\
\hline $\mathrm{TSP}(\mathrm{g} / \mathrm{km})$ & 0.01 & 0.53 & 1.4 \\
\hline $\mathrm{NO}_{\mathrm{x}}(\mathrm{g} / \mathrm{km})$ & 2 & 3.5 & 17.7 \\
\hline $\mathrm{SO}_{2}(\mathrm{~g} / \mathrm{km})$ & 0.026 & 0.44 & 0.82 \\
\hline $\mathrm{HC}(\mathrm{g} \cdot \mathrm{km})$ & 4 & 0.2 & 1.8 \\
\hline $\mathrm{CO}(\mathrm{g} / \mathrm{km})$ & 40 & 3.8 & 8.4 \\
\hline $\mathrm{CO}_{2}(\mathrm{~g} / \mathrm{km}$ fuels $)$ & 3180 & 3172 & 3172 \\
\hline $\mathrm{CH}_{4}(\mathrm{~g} / \mathrm{km})$ & 0.07 & 0.01 & 0.01 \\
\hline $\mathrm{N}_{2} \mathrm{O}(\mathrm{g} / \mathrm{km})$ & 0.005 & 0.014 & 0,031 \\
\hline $\mathrm{KLH}=\mathrm{Kementerian}$ Lingkungan Hidup dan Kehutanan (Ministry of Environment \& Forestry of
\end{tabular}
Republic Indonesia)

\section{RESULT AND DISCUSSION}

\section{A. The Balances of Supply and Demand}

The estimated daily consumption of fruit juice from all hotels in the zoning ofthe company's customers has been calculated at 42.337 liters, using O'Neil and Nicklas (2008) research the average specific gravity is 1,021 , juice weight equivalent to $43.250 \mathrm{~kg}[11]$. Weight transformation is required for loading of transport during transportation.

Factory production is obtained from the research of Hermawan and Sawarni (2014) where Pasteurized Juice is $227,947 \mathrm{~kg}$ per month or 56,987 per week [6]. The products are to fulfilling the Hotel Restaurant market and Consumer Pack. The Hotel only gets allocation 43,310 kg per week.

Considering the hotels market is concentrated in Jakarta, the company provides transit warehouse in Jakarta with the capacity to accommodate $30 \%$ of hotel needs. Thus the supply can be done through two delivery sources.

\section{B. Traveling Route Analysis}

Delivery is done using small refrigerated truck with capacity of 1.5 Ton. The company's fruit juice products use only 5-liter and 1 liter jerry can packs, not yet using Aseptic Packaging so that the product's durability is generally less than two weeks, so the distribution process is decided on a weekly basis with the re-use packaging system. Average travel and vehicle mileage are presented in Table 2.

Table 2. Average distance, time, and speed of delivery of fruit juice products to every hotel zoning from small and medium industry case customers

\begin{tabular}{|c|l|c|c|c|c|c|c|}
\hline \multirow{2}{*}{ No } & \multirow{2}{*}{ Zone } & \multicolumn{3}{|c|}{ Factory Warehouse } & \multicolumn{3}{c|}{ Jakarta Transkit Warehouse } \\
\cline { 3 - 8 } & & Normal & Traffic Jam & Eq. Distance & Normal & Traffic Jam & Eq. Distance \\
\cline { 3 - 8 } & & $\mathbf{( k m )}$ & $\mathbf{( k m )}$ & $\mathbf{( k m )}$ & $\mathbf{( k m )}$ & $\mathbf{( k m )}$ & $\mathbf{( k m})$ \\
\hline 1 & Jakarta(JKT) & 39.9 & 13.80 & 53.70 & 13.9 & 9.06 & 22.96 \\
\hline 2 & Bogor(BOO) & 91.5 & 11.76 & 103.26 & 50 & 20.20 & 70.20 \\
\hline 3 & Tangerang(TNG) & 20.2 & 10.25 & 30.45 & 32.3 & 15.50 & 47.80 \\
\hline 4 & Bekasi(BKS) & 61.8 & 15.79 & 77.59 & 22.4 & 14.29 & 36.69 \\
\hline 5 & Puncak(PUN) & 117.4 & 26.72 & 144.12 & 79.1 & 31.30 & 110.40 \\
\hline 6 & Serang(SRG) & 57.1 & 11.18 & 68.28 & 87 & 4.82 & 91.82 \\
\hline 7 & Depok(Dpk) & 54.8 & 25.36 & 80.16 & 16.6 & 13.19 & 29.79 \\
\hline 8 & Anyer(Any) & 124.9 & 30.92 & 155.82 & 133.6 & 38.20 & 171.80 \\
\hline 9 & Lido(LDO) & 111 & 25.44 & 136.44 & 69.6 & 30.18 & 99.78 \\
\hline
\end{tabular}

Some very remote hotels such as Tanjung Lesung, Cianjur, and Purwakarta, are only calculated up to the midpoint of the zoning city, considering the number is not too much and the travel path has been spared from the traffic density.

Based on Table 2 it appears that the average vehicle distribution speed is below the optimum speed, even using the highway. The minimum speed limit on highway is $60 \mathrm{Km}$ / hr. According to a World Bank report (2017), the average loss of time due to traffic jam in Jakarta is 3.5 hours a day [18]. The analysis of the delay of adding time due to traffic jam on the delivery of fruit juice to the hotel in the designated zoning is presented in Table 3.

Table 3. Calculation of delivery time of fruit juice and additions due to the traffic jam

\begin{tabular}{|c|l|c|c|c|c|c|c|}
\hline \multirow{2}{*}{ No } & \multirow{2}{*}{ Zone } & \multicolumn{3}{|c|}{ Factory Warehouse } & \multicolumn{3}{c|}{ Jakarta Transkit Warehouse } \\
\cline { 3 - 8 } & & $\begin{array}{c}\text { Normal } \\
\text { Time }\end{array}$ & Real Time & Traffic Jam & $\begin{array}{c}\text { Norma } \\
\text { Time }\end{array}$ & Real Time & Traffic Jam \\
\cline { 3 - 8 } & $(\mathbf{m i n})$ & $(\mathbf{k m})$ & $\mathbf{( k m})$ & $\mathbf{( k m )}$ & $\mathbf{( k m )}$ & $\mathbf{( k m )}$ \\
\hline 1 & Jakarta(JKT) & 39.90 & 61 & 21.10 & 13.90 & 39.90 & 26.00 \\
\hline 2 & Bogor(BOO) & 91.50 & 105 & 13.50 & 50.00 & 83.90 & 33.90 \\
\hline 3 & Tangerang(TNG) & 20.20 & 41 & 20.80 & 32.30 & 62.10 & 29.80 \\
\hline 4 & Bekasi(BKS) & 61.80 & 83 & 21.20 & 22.40 & 61.90 & 39.50 \\
\hline 5 & Puncak(PUN) & 117.40 & 152 & 34.60 & 79.10 & 130.90 & 51.80 \\
\hline 6 & Serang(SRG) & 57.10 & 71 & 13.90 & 87.00 & 92.10 & 5.10 \\
\hline 7 & Depok(Dpk) & 54.80 & 102 & 47.20 & 16.60 & 80.90 & 64.30 \\
\hline 8 & Anyer(Any) & 124.90 & 166 & 41.10 & 133.60 & 187.10 & 53.50 \\
\hline 9 & Lido(LDO) & 111.00 & 144 & 33.00 & 69.60 & 122.90 & 53.30 \\
\hline
\end{tabular}




\section{Environmental Burden Optimization in Distribution Pathways for Fruit Juice Product of Small Medium Enterprises Industry}

\section{Product Distribution Optimization}

Optimization is done for two reasons: 1) distance and 2) the travel time (duration). Both calculations are performed using the Vogel method to distribute juice products from two delivery sources. The calculations done for these two considerations, after going through 10 iterations give the same optimization results as presented in Table 4.

Table 4. Distribution of juice products optimally to all market zones

\begin{tabular}{|c|c|c|c|c|}
\hline \multirow{2}{*}{ Zones } & \multicolumn{2}{|c|}{ Factory Warehouse } & \multicolumn{2}{c|}{ Jakarta Transit Warehouse } \\
\cline { 2 - 5 } & $\mathrm{Kg}$ & Truck & $\mathrm{Kg}$ & Truck \\
\hline Jakarta & 18,949 & 13 & 12,993 & 9 \\
\hline Bogor & 3,114 & 3 & & \\
\hline Tangerang & 1,792 & 2 & & \\
\hline Bekasi & 1,281 & 1 & & \\
\hline Puncak & 3,579 & 3 & & \\
\hline Serang & 853 & 1 & & \\
\hline Depok & 276 & 1 & & \\
\hline Anyer & 306 & 1 & & \\
\hline Lido & 107 & 1 & & \\
\hline Total amount & 30,257 & 26 & 12,993 & 9 \\
\hline
\end{tabular}

The largest distribution in accordance with its needs is the Jakarta Zone of $31.942 \mathrm{~kg}$. A total of $40.68 \%$ of Transit Warehouse Jakarta supplied, thus the entire transit warehouse activities only serve zones Jakarta. Meanwhile, Zones other than Jakarta are all supplied from factories in Tangerang.

The optimum allocation results are further converted into a 1.5 Ton Truck Transportation (Vehicle) unit. By changing the distribution unit as the number of trucks, then the calculation of the optimal value $(Z)$ is entirely in the form of mileage travel (Trip) from and back to the source of supply. The results of these calculations facilitate the calculation of environmental burden.

Even if the optimization results of the distribution are the same, the optimal calculation result (Z) of the two considerations is different as follows:

$$
\begin{array}{ll}
\text { a. } & \mathrm{Z}_{\text {opt }}(\text { Distance })=3,441.00 \mathrm{Km} \text { per week } \\
\text { b. } & \mathrm{Z}_{\mathrm{opt}}(\text { Duration })=4,452.16 \mathrm{Km} \text { per week }
\end{array}
$$

Due to traffic jam consideration (Duration), the mileage equivalence becomes longer.

\section{Optimization Reroute}

Optimization results show that some zones have demand for no more than one delivery truck per week, so it becomes wasteful if it is served separately. Distributed line distribution can be reroute to be served by the same truck. Some of the rearranged paths are:

a. The Depok, Bogor and Lido zones formed a new line into the "Bodeli" Zone;

b. Serang and Anyer zones formed a new line into "Serang" Zone.

The arrangement is presented in Table 5 and the results reduce the number of trucks moving each week by 3 units. The optimal distribution path map is shown in Fig. 3. Next calculated the latest optimal $\mathrm{Z}$ value after the path reset as follows:

$$
\begin{array}{ll}
\text { a. } & \mathrm{Z}_{\text {opt }}^{\prime}(\text { Distance })=3.112 .20 \mathrm{Km} \text { per week } \\
\text { b. } \quad \mathrm{Z}_{\text {opt }}^{\prime}(\text { Duration })=4,081.45 \mathrm{Km} \text { per week }
\end{array}
$$

The optimal schedule reset results in shorter Z, so it is better.
Table 5. Reroute of fresh juice distribution path

\begin{tabular}{|c|c|c|c|c|c|c|}
\hline \multirow{2}{*}{ New Zone } & \multicolumn{3}{|c|}{ Factory Warehouse } & \multicolumn{2}{c|}{ Jakarta Transit Warehouse } \\
\cline { 2 - 7 } & Truck & $\begin{array}{c}\text { Distance } \\
(\mathrm{km})\end{array}$ & Trip $(\mathrm{km})$ & Truck & $\begin{array}{c}\text { Distance } \\
(\mathrm{km})\end{array}$ & Trip $(\mathrm{km})$ \\
\hline Distance Consideration & & & & & & \\
\hline Jakarta (JKT) & 13 & 39.90 & $1,037.40$ & 9 & 13.90 & 250.20 \\
\hline Bogor-Depok-Lido (Bodeli) & 3 & 111.00 & 666.00 & & 69.60 & 0.00 \\
\hline Tangerang (TNG) & 2 & 20.20 & 80.80 & & 32.30 & 0.00 \\
\hline Bekasi (BKS) & 1 & 61.80 & 123.60 & & 22.40 & 0.00 \\
\hline Puncak (PUN) & 3 & 117.40 & 704.40 & & 79.10 & 0.00 \\
\hline Serang-Anyer (Seran) & 1 & 124.90 & 249.80 & & 133.60 & 0.00 \\
\hline Total & 23 & & $2,862.00$ & 9 & & 250.20 \\
\hline Duration Consideration & & & & & & \\
\hline Jakarta (JKT) & 13 & 53.70 & $1,396.24$ & 9 & 22.96 & 413.24 \\
\hline Bogor-Depok-Lido (Bodeli) & 3 & 136.44 & 818.63 & & 99.78 & 0.00 \\
\hline Tangerang (TNG) & 2 & 30.45 & 121.79 & & 47.80 & 0.00 \\
\hline Bekasi (BKS) & 1 & 77.59 & 155.17 & & 36.69 & 0.00 \\
\hline Puncak (PUN) & 3 & 144.12 & 864.74 & & 110.40 & 0.00 \\
\hline Serang-Anyer (Seran) & 1 & 155.82 & 311.65 & & 171.80 & 0.00 \\
\hline Total & 23 & & $3,668.22$ & 9 & & 413.24 \\
\hline
\end{tabular}

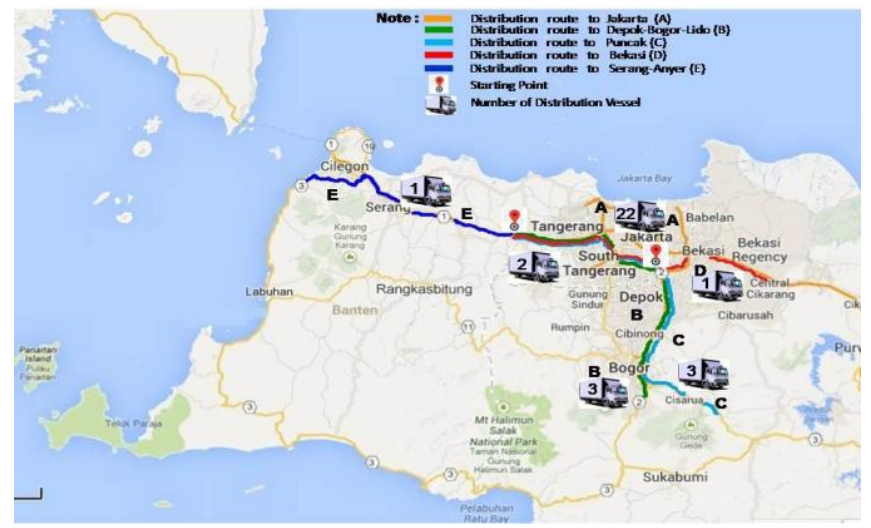

Fig. 3. The optimal distribution path of fruit juice to various distribution zones, the result of optimizing using Vogel reroute

\section{E. Environmental Burden Analysis}

Based on the optimal distance travel during product distribution in one week, predictable amount of fuel consumption.Diesel consumption for 1-2 years old truck according to Purnoto (2016) average 1 liter for $7.5 \mathrm{~km}$ [13]. Thus, using the IPCC (2006) method [7] calculated the use of diesel fuel for:
a. Zopt $($ Distance $)=415.0$ liters $/$ week
b. Zopt $($ Duration $)=544.2$ liters $/$ week .

Fuel consumption will be directly correlated with exhaust gas emissions of combustion. The use of fuel after considering the traffic jam factor when transporting, becomes larger than just calculating the distance. as presented in Fig. 4.

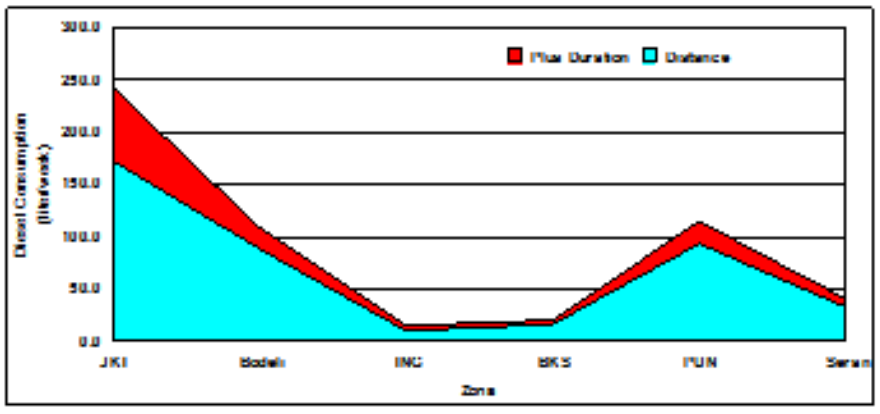

Fig. 4. Suppose of diesel fuel consumption truck distribution of fruit juice to various hotel zoning customers using IPCC method (2006) 
The $\mathrm{CO}_{2}$ gas emissions are calculated using the Barrel Oil Equivalent (SBM-Indonesian calculation). The result of mapping per zonation is calculated in Fig. 5. Distribution of fruit juice with observed to optimal distance, calculated to contribute $\mathrm{CO}_{2}$ amounted to $1220.35 \mathrm{~kg}$ per week, and consideration of $\mathrm{CO}_{2}$ contributed mileage of $1600.41 \mathrm{~kg}$ per week.

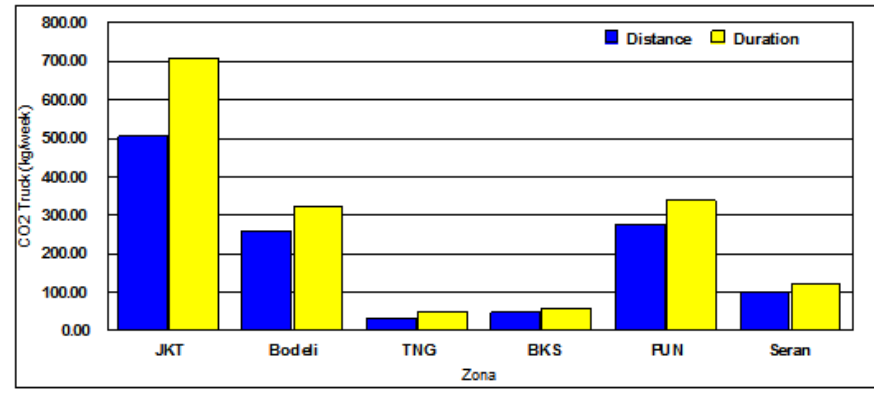

Fig. 5. CO2 emissions suppose from diesel truck combustion of fruit juice distribution to various hotel zoning customers using IPCC method (2006)

Calculations which considering the duration or duration of the distribution of fruit juices contribute to huge pollution loads, especially in the Jakarta zone as presented in Fig. 6. The traffic jam level in Jakarta is much larger than other zones, while only distribution to the non-crossing Serang-Anyer zoneof Jakarta city.

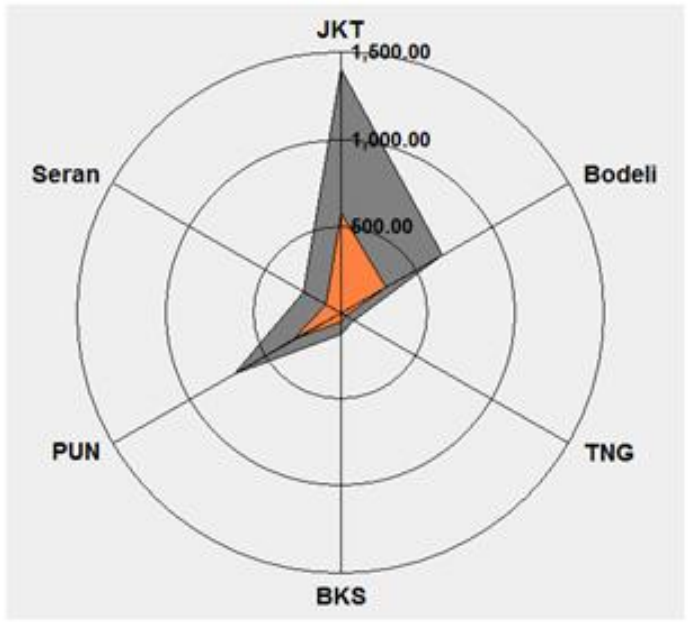

Fig. 6. Distribution of $\mathrm{CO}_{2}$ load from diesel truck combustion of fruit juice transportation

The calculation of the estimated exhaust emissions from vehicle transportation for fruit juice distribution using the conversion method is presented in Fig. 7. The $\mathrm{CO}_{2}$ emissions per week, the highest compared to other gases reaches $1,316.25 \mathrm{~kg}$ for calculation only at distances, while for consideration of emission travel timeof $\mathrm{CO}_{2}$ gas reaches $1,726.18 \mathrm{~kg}$.

Both methods of calculation using the IPCC (2006) [7] and conversion method using KLH guidance (2013) [9] for $\mathrm{CO}_{2}$ emission there is a difference of about $100 \mathrm{~kg}$ per week. The research of Tiaraniet al (2016) also gives different results [16], but more support KLH method (2013) because it has been adjusted to the condition of Indonesia.

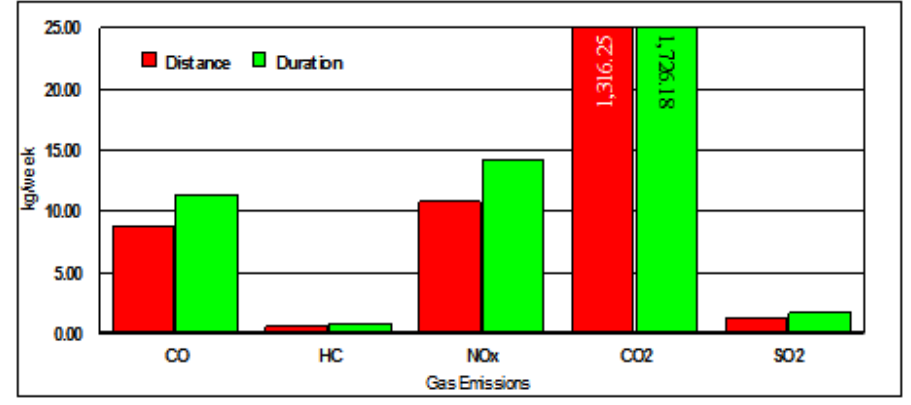

Fig. 7. Estimated exhaust emission load from diesel truck combustion of fruit juice distribution to various hotel zoning customers using KLH method (2013)

\section{CONCLUSION}

The SME's fruit juice products in Jabotabek, must be distributed to hotel customers for weekly consumption, due to product durability of less than 30 days. The hotel served by the pilot company is predicted to require $43,250 \mathrm{~kg}$ per week. The distribution of products is done from the factory warehouse and the Jakarta transit warehouse. Optimal conditions show that the fabric warehouse will supply 23 Trucks of 1.5 Ton capacity and 5 Jakarta Truck warehouse each week.

The optimal distribution of fruit juice products is estimated to use 414.96 liters of diesel fuels per week when only calculating mileage or distance. However, with the calculation of the traffic jam, the consumption of diesel oil can reach 544.19 liters per week. The environmental burden due to pollution of $\mathrm{CO}_{2}$ gas remaining fuel combustion from such distribution transport reaches at least 1.22-1.32 Ton $\mathrm{CO}_{2}$ / week without traffic jam and 1.60-1.73 Ton $\mathrm{CO}_{2}$ / week with traffic jam.

The reducements of exhaust emissions can still be recommended by improving the distribution channels through more detailed route calculations, especially Jakarta. In addition, the operational conditions of the vehicles used must be kept in a well maintained.

\section{ACKNOWLEDGE}

1. Computer Science Program, Universitas Pakuan-Bogor

2. Magister Program of Industrial Engineering, Universitas Mercubuana-Jakarta

3. Integrated Laboratory Certification Body of Bogor Agriculture Institute, for contribution of customer data of Fruit Juice industry certification

\section{REFERENCES}

1. Central Bureau of Statistics RI. Export-Import Statistics Data. Limited Publication. 2018

2. S. Chopra andP. Meindl. Supply Chain Management: Strategy Planning, and Operation, New Jersey: Pearson Publisher, 2010.

3. Department of Industrial Affair RI.Roadmap of Fruits Processing Industry.Jakarta: Director General Agro \& Chemical Industries, Department of Industrial Affair. 2009.

4. European Commission. Transport and The Environment. Brussel: Directorate General for Energy and Transport European Commission, 2009.

5. T. Hermawan. "Sistem Manajemen Rantai Pasokan Ramah Lingkungan.”Buletin Penelitian Universitas Djuanda. vol.12, no.1. pp. 8-17, 2007. 
6. T. Hermawan andH. Sawarni. "Analisis Keseimbangan Bahan pada Kaji Awal Lingkungan, Perencanaan Sistem Manajemen Lingkungan ISO 14001:2004 Industri Minuman Sari Buah."Industrial Engineering Conference, pp. 90-99, 2014.

7. IPCC (Intergovernmental Panel on Climate Change). Guidelines for National Greenhouse Gas Inventories. Section 4: Agriculture. 2000.

8. $\quad$ Ministry of Energy and Mineral Resources. Study of Greenhouse Gas Emissions - Transportation Sector. Jakarta: Center for Energy and Mineral Resources Data and Information, 2012.

9. Ministry of Environment and Forestry. Technical Guidelines for Preparation of Emissions Inventory of Urban Air Pollutants. Jakarta: Deputy Assistant of Movable Source of Air Pollution Control Deputy for Environmental Pollution Control of the Ministry of Environment Air Pollution in the Region, 2013.

10. M. Markley and Davis. "Exploring future competitive advantage through sustainable supply chains."International Journal of Physical Distribution \& Logistics Management. vol. 37, no. 9. pp, 763-774, 2007.

11. C. E. O'Neil and T.A. Nicklas."A Review of the Relationship Between 100\% Fruit Juice Consumption and Weight in Children and Adolescents."American Journal of Lifestyle Medicine. vol2, no. 4, pp. 315-354, 2008

12. Y. Prambudia and A.A. Nur. "The Effect of Considering Environmental Aspect to Distribution Planning: A Case in Logistics SME."IOP Conf. Series: Materials Science and Engineering. Vol. 105,pp. 012029, 2016.

13. S. Purnoto."Tantangan dan strategi truk angkutan barang dalam menciptakan keunggulan bersaing. " Seminar Suplly Chain Indonesia pp. 25-26, 2016.

14. S. Satuhu. Penanganan dan pengolahan buah.Jakarta: PT Penebar Swadaya, 2004

15. S. Seuring and M. Müller. Integrated chain management in Germany - identifying schools of thought based on a literature review. Journal of Cleaner Production, vol. 15, no. 7, pp. 699-710, 2007.

16. V. L. E. Tiarani, Sutrisno and H. S. Huboyo. "Kajian Beban Emisi Pencemar Udara (Tsp, $\mathrm{NO}_{x}, \mathrm{SO}_{2}, \mathrm{HK}, \mathrm{CO}$ ) Dan Gas Rumah Kaca $\left(\mathrm{CO}_{2}, \mathrm{CH}_{4}, \mathrm{~N}_{2} \mathrm{O}\right)$ Sektor Transportasi Darat Kota Yogyakarta Dengan Metode Tier 1 Dan Tier 2."Jurnal Teknik Lingkungan, vol 5, no. 1, pp. 1-10, 2017.

17. H. Walker, L. Sistoand D. McBain. "Drivers and barriers to environmental supply chain management practices: Lessons from the public and private sectors."Journal Purchasing andSupply Management, vol. 14, no. 1, pp. 69-85, 2008.

18. Word Bank Group. Indonesian Economic Review. Word Bank Quarterly Report. http://www.worldbank.org/en/country/indonesia/publication/indonesi a-economic-quarterly-reports. Acces 10 June 2018.

19. H. Zahra and Driejana. Perbandingan Estimasi Beban Emisi CO Dan $\mathrm{CO}_{2}$ dengan Pendekatan Konsumsi Bahan Bakar Dan Kecepatan Kendaraan (Studi Kasus : Bunderan Cibiru-Lembang). Bandung:InstitutTeknologi Bandung, 2008. 